\title{
China's automobile Import and Export Trade Status Analysis Based On The Product Life Cycle Theory
}

\author{
Hu Yongjun \\ Guangzhou Maritime Institute, Guangzhou, China \\ e-mail: huyongjunhyj@126.com
}

\begin{abstract}
China's automobile import and export trade was a deficit in the state, especially the automobile trade deficit is more prominent. This paper studies the status and development trend of China's auto export trade, and to explore the opportunities and challenges that China's auto exports face after the accession to the WTO and the financial crisis, and reveal the causes and solutions of China blocked the export of cars in recent years, and ultimately promote the healthy development of China's auto export trade.
\end{abstract}

Keywords-the product life cycle; China's automobile industry; new energy vehicle

\section{CHINA'S AUTOMOBILE IMPORT AND EXPORT TRADE SITUATION}

After entering the 21st century, China's auto industry is developing rapidly, and formed many varieties, a full range of vehicle and parts production and supporting system, improve industrial concentration, obviously improve the product technology, playing a more and more important role in the world. Especially after 2004, the Chinese cars exported every year with $100 \%$ of the growth momentum, parts exports also maintained the growth rate of around $50 \%$. Since the second half of 2008, with the spread of the international financial crisis and the deepening of the international automobile market is serious, and it impact domestic automobile market seriously. Then China's automobile import and export situation had a severe downturn and the development situation was bad. In 2010, the latest automobile import and export data made by General Administration of Customs show that China's auto production export is gradually rise steadily.

\begin{tabular}{cccc} 
TABLE I. & $\begin{array}{c}\text { CHINA'S AUTOMOBILE IMPORT AND EXPORT TRADE } \\
\text { DATE (INCLUDING AUTOMOTIVE) }\end{array}$ \\
\hline Export & $\begin{array}{c}\text { The value volume } \\
\text { of trade } \\
\text { (hundred million } \\
\text { dollars) }\end{array}$ & $\begin{array}{c}\text { The growth } \\
\text { rate }\end{array}$ & Region \\
\hline Import & 467.68 & 42.82 & $\begin{array}{c}\text { Algeria, Vietnam, } \\
\text { Egypt, Iran, Syria } \\
\text { and so on } \\
\text { Germany Japan the }\end{array}$ \\
& 507.74 & 76.79 & $\begin{array}{c}\text { United States, South } \\
\text { Korea, the United } \\
\text { Kingdom and so on }\end{array}$ \\
\hline
\end{tabular}

As shown in Table1, from January to November in 2010, the amount of the total import and export about the national automobile products (including auto parts) was more substantial growth, and year-on-year growth rate was $76.79 \%$ and $42.82 \%$, respectively. Further analysis can be found that the import trade volume is higher than the export volume of $8 \%$, and the growth rate of the import trade was much faster than the growth rate of the export trade. The trade deficit amounted to \$ 4.006 billion. One thing to notice was that China's auto parts was a great content. Because the car overall trade situation more accurately reflect the level of production technology of the automobile industry in China as well as the state of competition in the international market, so we do out of the auto parts trade further analysis. Based on September 2010 data provided by the General Administration of Customs, we have produced Table 2.

TABLE II. CHINA'S AUTOMOBILE IMPORT AND EXPORT TRADE DATE IN SEPTEMBER, 2010

\begin{tabular}{|c|c|c|c|}
\hline & $\begin{array}{c}\text { The volume of } \\
\text { the trade(ten } \\
\text { thousand) }\end{array}$ & $\begin{array}{c}\text { The value of } \\
\text { trade } \\
\text { (hundred million } \\
\text { dollars) }\end{array}$ & Region \\
\hline Export & 5.14 & 5.98 & $\begin{array}{l}\text { Algeria, Vietnam, } \\
\text { Egypt, Iran, Syria } \\
\text { and so on }\end{array}$ \\
\hline Import & 6.63 & 23.13 & $\begin{array}{l}\text { Germany Japan the } \\
\text { United States, South } \\
\text { Korea, the United } \\
\text { Kingdom and so on }\end{array}$ \\
\hline
\end{tabular}

As shown in Table 2, in September, 2010, China's total imports of vehicle was 66,300 and the volume of import trade was 2.313 billion dollars. And the export cars was 51,400 , the export trade volume was $\$ 598$ million. From a trade point of view, the number of imported cars was more than export cars about 14,900. From the view of the volume of trade, import trade volume of nearly four times to the export. The automobile trade deficit amounted to \$ 1.65 billion. Compared with trade deficit level of automobile products (including auto parts) from January to November,2010, the car trade deficit was apparently larger in China.

If $\$ 1$ is equal to 6.6 Yuan exchange rate and trade volume divided by the number of cars method to calculate the average price, the average price of imported cars in China in September was 230,300 Yuan, the average price of the exported car is only 76,800 Yuan. This shows that Chinese exports to the Middle East, Southeast Asia, Latin America, Africa and other developing countries and regions, was mainly cheap cars, And the imported cars from the developed Europe, the United States, Japan and South Korea were high-end cars. That further illustrates 
the production technology and competition of China's automobile industry there had a big gap compared with the large foreign car company.

\section{THE CHINA'S AUTOMOBILE IMPORT AND EXPORT TRADE SWOT ANALYSIS BASED ON THE PRODUCT LIFE} CYCLE THEORY

\section{A. The Strength}

\section{1) The cost advantage}

China has the world's largest labor market. And automobile production that needs more labors will move into the Chinese market from the western market. China use cheap labor as a competitive advantage, and reduced the cost of the automobile production. There is no doubt that China will eventually become the world's largest automobile production and exporter in the near future. It's like the past textile industry transferred to China from Europe and the United States. The car industry will also be transferred from the pod, Korea and Japan regions to China. And automobile industry will get vigorous development in China.

\section{2) Good economical policy environment}

The first half of 2009, the General Office of the State Council promulgated the "automobile industry restructuring and revitalization plan." The plan more focused directly on the reorganization of the auto companies, new energy vehicles, and the development of its own brand, targeted and forward-looking strategic guidance. This is conducive to the Chinese-made cars to the world. It is also very beneficial in terms of the economic environment, such as the level of integrated industrial and continuously improves, labor disputes, and the continued rapid growth of the national economy. Pointed out that in the automotive industry planning rules, the State Council issued the "4-5, to be formed through mergers and acquisitions, the 2-3 large enterprise groups, the scale of production and marketing of more than 2 million breed-scale production and sales of over one million automobile enterprise groups, the scale of production and sales accounted for more than $90 \%$ of the market share of the number of automobile enterprise group to reduce from the current 14 to 10 or less. This will give a strong impetus to the rapid development of China's automobile industry.

3) High-tech energy - saving REDD product has strong competitive

High-tech energy - saving REDD products are in the market growth stage of the product life cycle. And energysaving and REDD is the future trend of the development of the automotive industry. That means that industry sales grow fast, and industry profits rise.

In 2009, the North American International Auto Show show that the saving energy will become the biggest selling point which attracts consumers in each booth. The new energy automotive industry will be developed in the market of the developing countries, and they will get a more broad space for development. China's Ministry of
Finance and Ministry of Science and Technology jointly issued the "energy - saving and new energy vehicle demonstration and extension of financial assistance funds Interim Measures for the Administration." Objects and standard of subsidies were given by the central government on the purchase of energy - saving and new energy vehicles. According to the notice released by the Ministry of Finance, China will carry out energy-saving and new energy vehicle demonstration and extension of the pilot work. The financial support for energy-saving and new energy vehicles refers to hybrid vehicles, pure electric vehicles and fuel cell vehicles. The saving rate hybrid cars whose saving rate is more than $40 \%$, the subsidies will reach 50,000 Yuan. And the government encouraged people to take the lead in promoting new energy vehicles in public services such as public transportation, rental. Because the growing scarcity of traditional energy sources increases environmental issues, development and utilization of new energy sources has become increasingly urgent. In this area, the gab between our country with the world is not big. Though we have been reached or exceeded the world level in some aspect. Development of new energy vehicles and energy - saving REED high-tech products will improve the international competitiveness of China's car.

\section{B. The Weakness}

\section{1) The disadvantage of technology and brand}

In terms of automobile, put aside the differences in appearance and additional local function, the most important difference between the Chinese automotive products and imports of automotive products lies in the technical level differences. It is this level of technology differences, so that automobile manufacturing in China and imported auto belong to different automobile products. Therefore, they have a different life cycle curve. Imported cars which represent the technical level of the automotive products named product 1 , the automotive products named product 2. In terms of China's current level of technology, consumer products about product 1 mainly rely on imports. China does not yet have the competitive advantage of the product 1 . China is still in the introduction stage of its product life cycle. It takes time to entry into the rapid growth for China. On our current level of technology products from the scale of production or consumption growth rate, the product 2 is in the growth stage of product life cycle, and the growth speed is its significant sign. Product technology is mature at this stage, but the product need plenty of money and a lot of skilled labor workers to maintain the large-scale production, and these conditions we currently have. Therefore, products production, China has a comparative advantage, our production not only to meet the high demand in the domestic market, but also a large number of exports to some of the relatively less developed countries and regions.

Our country on behalf of a high technical level, the lack of a competitive advantage of the high market price of the product 2 represents a relatively low technical level, the lower the market price of the product has a 
comparative advantage, resulting in little difference between the import and export quantity under a large trade deficit, which is unreasonable performance of China's automobile industry structure level. The stage of development of China's auto industry can be concluded prominent phenomenon of the trade deficit in the short term is difficult to be a fundamental change.

2) The effect of scale

One is that the scale of China's auto parts industry is large, but it did not produce large-scale effects. Second, due to the small size of the domestic auto manufacturing, the cost is much higher than the international average cost. That leads our low labor productivity, and it's difficult to defuse vehicle prices to bring down the cost pressures. Third, either domestic brands or joint venture product exports do not have the cost advantage of scale in the construction of transportation and after-sales network because of small-scale exports.

\section{3) The bad marketing management}

First of all, the marketing activities don't match with product value, and the different positioning products have taken the same marketing mix. For example, each auto show should have the best chance to collect consumer feedback, but many enterprises have been made them become beauty show. Secondly, exports of vehicles and spare parts services can not keep up, and some companies automobile exports on the bin outside, there is no aftersales service network and service personnel, and some car problems without timely supply of spare parts to repair personnel are not in place, these affect our car exports reputation and expand exports.

\section{The Opportunity}

Although the outbreak of the financial crisis, but the Chinese high-speed development in the past 30 years bears a huge potential demand for the car. In rural areas, the basic problem of food and clothing to resolve; housing problems in the city lot of heated discussions, but the main problems of the housing is weak contradiction of the high prices and the needs of the people, the people of weak demand the most fundamental reason is that most The people now have the house to live. The new demand is not hard to buy a house, but turned to another level of consumption, as compared to buy a house, buy a car cheaper buying a car has become the first choice of the residents improve their lives.

The existing policy of the state as well as low international oil prices is conducive to the revitalization of the automotive industry and the popularity of the new introduction of the automobile industry revitalization plan to play a role in the engine of the national economy on the automotive industry even more powerful. Fuel consumption tax reform introduced on January 1, 2009, have a profound impact on the development of the automotive industry. The burden is more reasonable to buy a car, and will promote the rapid development of the private car. The same time, lower international oil prices, forecasting agencies predict future international oil prices is likely to remain between $\$ 50-70$ per barrel. Now, the revitalization of the automobile industry plans and priority to the introduction of the vehicle purchase tax and car purchase mortgage support, so that people are not only able to afford a car costs, but also be able to buy a gas car, the automotive industry revitalization unstoppable.

China is the future of the global auto industry development in key areas, strong consumption power of the outbreak in the future of this market will be no irresistible force. Just facing with the current global financial crisis, the release of the demand is repressed, so no need to panic.

\section{The Threat}

\section{1) Export is still playing at a low price}

China's own brand car sales had the high-speed growth since last year, but not only did not bring the expected additional profits, but instead brought a sharp decline in profits. In addition, the average export price of the cars appeared to rebound in 2009, compared with the same period in 2008 increased by 5\%, but the export price of other models fall, specially purpose vehicles, the largest decline is $45 \%$.

2) The low technological level and poor quality of China's automobile

Introduction of foreign investment and expand cooperation at the same time, the absence of the Chinese automotive technically is a much more serious problem. In the joint venture, the foreign partner to China's technology, most of the technology matured even recession has begun. Car backward technology, the cost is relatively low, and will inevitably lead to the Chinese auto companies at a disadvantage in international competition. How the introduction of technology and technology development is a major issue. GM, Ford and other companies a year of research and development costs as high as 50 to 60 billion U.S. dollars; Audi company planning to build R \& D center focused on the essence of the whole company; while in our country, the automobile research and development costs of less than $2 \%$ of sales. Chinese cars are entering a vicious cycle "rely more can not afford the more, the more the more dependent and introduction backward - introduction - backward".

\section{3) Lake of independent core technology}

In recent years, the automotive industry-wide $\mathrm{R} \& \mathrm{D}$ investment accounted for a proportion of sales revenue is only about $0.6 \%$, unable to form a strong development capacity, lack of key parts of the core technology. China's auto exports did not form their own strong brand, relative to the rapid development of production capacity and yield, and there is no breakthrough in the automotive industry in China since the independent intellectual property rights, or brand, and hard to break abroad in performance, environmental protection and other aspects of technical barriers this makes China's auto exports face a bottleneck. Beijing Hyundai series plans to export to Eastern Europe encounter partners to vigorously obstruct or Chery suffered frequent intellectual property litigation, and Geely Malaysia vehicle blocked the export items. This show, Europe and the United States is the use of technology, 
environmental protection and other barriers to restrict cheap Chinese car to enter the market. For example, China's heavy-duty trucks to enter the European market, there is a provision that is the engine of the car must meet European standards, otherwise it will not be able to enter the markets of the region. However, most of the market of China's engine let Cummins occupy our Weichai engine market and in line with European standards, but to some extent, is still a gap compared with developed countries.

4) The problem intellectual property right

At present, in addition to China's independent automobile brands which have intellectual property rights as Chery, Geely, BYD, JinLong, Pentium, half of China's auto consumption market is still firmly occupied by foreign brands. Our own automotive products accounted for sales of the entire passenger car production ratio of about 25\%, with foreign countries, we are so low; $70 \%$ of the market occupied by international brands.

5) Fluctuations in exchange rates, the impact of the appreciation of the $R M B$

Affected by fluctuations in exchange rates, the price advantage of China's car gradually lost. First, domestic exports of automotive products was not very high-end, high value-added, low profits, an appreciation of the RMB, the manufacturers of export profits will face dropped; once again, the appreciation of the RMB, but won other currencies relative to the U.S. dollar still devaluation, originally of China's exports of automotive products relative to no price advantage for Korean products, this way, the only advantage will be lost, which is very conducive to the enhancement of the global competitiveness of the automotive products, also is not conducive to the development of the domestic auto industry. Vehicle and parts exports to its own brand cars appreciation of the RMB in the short term may be a blow to a certain extent, will slow the pace of China's automotive exports, less favorable for its own brand to open up overseas markets, China's auto exports face huge pressure.

6) Export transportation problem

China don't has enough volume of exports, specifically can't afford the ro-ro transport vehicle exports, the car is facing a backlog at the port shipped out. The high cost of ro-ro, before China's auto exports of scale, a small amount of exports would certainly face can not afford to ro-ro ships, or the plight of other goods mixed. Before the arrival of the large-scale export, shipping will always be a bottleneck. Most of the domestic automobile manufacturers currently export orders from time to time, often no alternative but to take on Japanese and Korean shipping companies expensive retail price, while Japan and South Korea national automobile export enterprises, but because the long-term agreements and even shares of shipping companies enjoying the benefits of the "wholesale".

7) The impact of the financial crisis

First of all, by the impact of the international financial crisis, the world automobile market demand declined significantly, at the same time, corporate finance suffered a serious blow, the credit business is difficult to carry out, to reduce a lot of consumer demand.

Followed by the birth of a new round of financial crisis, trade protectionism, Countries have introduced policies to restrict car imports, Russia imports 15\% -30\% increase in tariffs on imported tires and vehicle, Argentina, Venezuela import licensing system were taken. At the same time, the quality and technical performance of the export cars need to adapt to the characteristics of different regions in different countries in the international market, the social environment, natural environment, geographical conditions and even the human environment, however, countries in varying degrees respectively to enhance the performance of the financial crisis and environmental protection technical barriers, making itself the low starting point, technically with international standards gap between China's automotive industry is facing a severe test, our automotive products in order to successfully achieve the export, must as soon as possible to break a lot of technical bottlenecks.

\section{THE SELECTION OF DEVELOPMENT STRATEGY}

Though the analysis of the product life cycle theory, we believe that China's auto industry trade deficit outstanding issues with inevitability and a fundamental change in the short term is difficult. Develop appropriate strategies to change the current situation as soon as possible, we must solve the problem to enhance the level of the structure of China's automobile industry and industrial competitiveness.

Here, some specific countermeasures choose on the development of the automobile industry, such as increased research funding to improve the technical level, to enhance the self-development capacity, improve the consumption policy is not to emphasize herein, the paper argues that the country should be in the industrial development of the overall the strategic choice of a new positioning within the industry to break the traditional structure evolution path, the use of relevant industrial policies, accelerate the process of the automotive industrial structure upgrade.

In different stages of the product life cycle, the dependence of the different factors of production is different, with different elements of reserve conditions in various countries and regions, which form the comparative advantage of the differences between the different flows as well as import and export of products. The variable products need to experience the different stages of the life cycle, and factors of production, so the comparative advantage in the changing. With China's rapid economic development and the constant improvement of the conditions, the hierarchy of factors of production has also been upgraded.

\section{REFERENCES}

[1] Duval, Y. and Utoktham, C. Behind-the-Border Trade Facilitation in Asia-Pacific: Cost of Trade, Credit Information, Contract Enforcement and Regulatory Coherence. UNESCAP Trade and 
Investment Division, Staff Working Paper 02/09, UNESCAP, Bangkok, 2009.

[2] Ramasamy, B. Free Trade Agreements and International Production Networks: China and the Automotive Industry. ArtNet Research Project, 2009.

[3] Wilson, N. Examining the Trade Effects of Certain Customs and Administrative Procedures. OECD Trade Policy Working Paper No. 42, OECD, France, 2007.

[4] Tu Yingqing, Chen Wen. Discussion on the problems and path of China's automobile industry upgrading. Enterprise Economy No.6, 2011.

[5] Wang Xiaoshun. Analysis of the international competitiveness of China's automobile industry. Special Zone Economy No.12, 2008.

[6] Greene M, Tsai G. Enhancing market Openness Through Regulatory Reform in the People's Republic of China. OECD Trade Policy Working Paper No. 83, 2008.

[7] Yi Jingjing.Analysis of the competitiveness of Chinese automobile industry at the present stage -- Based on the double diamond model. China Collective Economy No.19, 2010.

[8] Xiao Liqiang. Analysis of Chinese auto industry product life cycle. Fujian Forum - Humanities and Social Sciences Edition, 2010. 